\title{
The Export Performance of the 2004 EU Enlargement Economies since the 1990s: a Constant Market Share Analysis
}

\author{
Maria Paula Fontoura ${ }^{1,2}$ (D) Pedro Serôdio ${ }^{1}$
}

Published online: 23 March 2017

C The Author(s) 2017. This article is published with open access at Springerlink.com

\begin{abstract}
This study focuses on the export performance of the 2004 European Union (EU) enlargement economies to the EU15 between 1990 and 2013. The long time span analysed allows to capture different stages in the relationship of these new members with the EU before and after accession. The study is based on the constant market share methodology of decomposing an ex-post country's export performance into different effects. Two constant market share analyses were selected in order to disentangle (i) the growth rate of exports and (ii) the growth rate of exports relatively to the world. Both approaches are applied to manufactured products grouping products in different classifications of sectors. Results provide information on export performance for the ten economies individually considered, including the importance of each EU15 destination market.
\end{abstract}

Keywords Export performance - Constant market share - European Union · 2004 European Union enlargement

JEL Classification F15 - O52

\section{Introduction}

On 1 May 2004, a treaty of accession between the first 15 member states of the European Union (EU15) and ten aspiring new member states came into force. Geographically located in Central and Eastern Europe, these ten countries included three

Maria Paula Fontoura

fontoura@iseg.ulisboa.pt

1 ISEG, Lisbon School of Economics and Management, University of Lisbon, Lisbon, Portugal

2 UECE (Research Unit on Complexity and Economics), Lisbon, Portugal 
former Soviet republics (Estonia, Latvia, and Lithuania), four former Soviet satellites (Poland, the Czech Republic, Hungary and Slovakia), a former Yugoslav republic (Slovenia) and two Mediterranean islands (Cyprus and Malta).

On the part of the accession countries, the 2004 EU enlargement led to high expectations of an increasing economic growth by having access to an economic union with high purchasing power. This study will focus on one of the major points to promote a country's economic growth: the export performance. The period analysed is a long time span, between 1990 and 2013, in order to capture different stages in the relationship of these new members with the EU before and after accession. The total period is decomposed into four sub-periods as follows. (1) From 1990 to 1996, corresponding to the phase of the fall of the Soviet Union and the applications of these ten countries for accession to the EU, this sub-period being not only a transition period but also a control period, in which accession negotiations had not yet started. (2) From 1996 to 2004, corresponding to the enlargement process. To prepare for EU membership, the EU supported the work of the candidate countries to adopt the community's rules through a pre-accession strategy previously signed which included financial assistance for developing their institutions, infrastructure and economies (EUR-Lex 2007). (3) From 2004 to 2008 , corresponding to the period between the accession and the financial crisis. (4) From 2008 to 2013, a period marked by the economic crisis of 2008.

In order to evaluate these ten economies' export performance to the EU15, this study makes use of the constant market share analysis (CMSA). This technique decomposes a country's export performance into separate components, comprehending not only product and market structure components of exports but also a residual effect associated with competitiveness. In this study, two different CMSAs will be used, thus enabling a broad evaluation of the effective changes of these ten economies' export performance. Although CMSA is a frequently used method to evaluate export performance, few studies have applied it to the 2004 enlargement countries. ${ }^{1}$ Relatively to previous studies, we not only resort to different decompositions of the CMSA but cover a longer time span, over diverse stages of European economic integration. In addition, we proceed to a detailed analysis of all economies of the 2004 EU enlargement using sectoral disaggregation.

The first CMSA is based on Leamer and Stern (1970) and examines the variation of a country's growth in exports. The second CMSA is based on Nyssens and Poullet (1990) and decomposes a country's growth rate of exports relative to the world. We consider the exports of 72 manufactured products as defined by the (CHELEM) Comptes Harmonisés sur les Echanges et L'Économie Mondiale International Trade database created by the Centre d'Etudes Prospectives et d'Informations Internationales (CEPII) research centre. This database contains the bilateral flows of traded goods expressed in millions of current dollars ${ }^{2}$ and FOB terms.

Results are presented for the whole set of the 72 products and by grouping them in two different classification of sectors based on Fernandes (2003), as shown in the

\footnotetext{
${ }^{1}$ Recently, Pavlíčková (2013) used it for Slovak exports to the EU27 in the 2000s. For a different methodology, see Allard (2009).

${ }^{2}$ A drawback of using nominal values is that it is not possible to distinguish between the volume and the price components of export performance.
} 
Appendix. The first is based on the classification of the Organisation for Economic Co-operation and Development (OECD) for technological intensity and is composed of three sectors: low, medium and high technological intensity. The second is based on the OECD's classification for specialization factors and is composed of five sectors: natural resources, labour costs, scale economies, product differentiation and R\&D.

\section{Methodology: Constant Market Share Analysis}

One of the first and most influential versions of the CMSA was made by Leamer and Stern (1970). This version specifically focuses on the effects underlying the percentage change in exports of a country. Although it is influencial, several reservations to this approach have been pointed out, especially by Richardson (1971). ${ }^{3}$ The main critique is that the product and market effects are calculated in an asymmetric way, and depending on which one is calculated first, one of them will include the interaction between the two effects (Richardson 1971; Cheptea et al. 2005). To solve this problem, Milana (1988) proposed to calculate this interaction effect (mixed effect) explicitly, a correction that has been largely applied ever since, for instance by the European Central Bank (ECB) in ECB (2005) and Amador and Cabral (2008).

Currently, several CMSAs have been used in order to evaluate the export performance of a country. One CMSA was proposed by Nyssens and Poullet (1990) and evaluates the change of a country's share of exports relative to the world. In this study, we apply the CMSAs of Leamer and Stern (1970) and Nyssens and Poullet (1990) with the interaction term proposed by Milana (1988) in both cases.

\section{Decomposing the Growth Rate of Exports}

The Leamer and Stern (1970) CMSA decomposes the export performance of a country (group of countries) taking into consideration the growth rate of exports.

The CMSA identity is expressed as:

$$
\underbrace{\frac{\Sigma_{i} \Sigma_{j} X_{i j, t}-\Sigma_{i} \Sigma_{j} X_{i j, t-1}}{\Sigma_{i} \Sigma_{j} X_{i j, t-1}}}_{\text {TOTAL EFFECT }}=\underbrace{\frac{\Sigma_{i} \Sigma_{j} S_{i j, t-1} \Delta X_{i j}^{*}}{\Sigma_{i} \Sigma_{j} X_{i j, t-1}}}_{\begin{array}{c}
\text { STRUCTURE } \\
\text { EFFECT }
\end{array}}+\underbrace{\underbrace{\Sigma_{i j, t} S_{i j} X_{i j, t}^{*}}_{\Sigma_{i} \Sigma_{j} X_{i j, t-1}}}_{\begin{array}{c}
\text { COMPETITIVENESS } \\
\text { EFFECT }
\end{array}}
$$

where $X$ corresponds to the nominal value of a country's exports; $X^{*}$ means the equivalent notion for world exports; $i$ is the category of manufactured goods (hereinafter "product"); $j$ corresponds to the EU15 destination market; $t-1$ and $t$ are the initial and final years, respectively; $S$ is the share of the analysed country's exports in the world exports; $\Delta X^{*}$ is the variation in world exports in period $t$ and $\Delta S$ in the variation in $\mathrm{S}$ in period $\mathrm{t}$.

\footnotetext{
${ }^{3}$ For a critical evaluation of this methodology see, for instance, Ahmadi-Esfahani (2006).
} 
The total effect corresponds to the total growth rate of exports of manufactured goods of the new EU member(s) to the EU15. It can be decomposed into two main effects: the structure effect and the competitiveness effect.

The structure effect, which Leamer and Stern (1970) referred as the demand side of the phenomenon under study, expresses the part of the growth rate of exports due to the variation of the world exports (to the same destination market), given the export structure of the analysed country in terms of products and destination markets of the initial period. The last term of the identity is the so-called competitiveness effect, which is commonly related to the exporter's price and non-price competitiveness.

The structure effect, in turn, can be decomposed into the following three effects:

$$
\begin{aligned}
& \underbrace{\frac{\Sigma_{i} \Sigma_{j} S_{i j, t-1} \Delta X_{i j}^{*}}{\Sigma_{i} \Sigma_{j} X_{i j, t-1}}}_{\text {STRUCTURE }}=\underbrace{\frac{\sum_{i} S_{i, t-1} \Delta X_{i}^{*}}{\sum_{i} \Sigma_{j} X_{i j, t-1}}}_{\text {PRODUCT }}+\underbrace{\frac{\sum_{j} S_{j, t-1} \Delta X_{j}^{*}}{\sum_{i} \Sigma_{j} X_{i j, t-1}}}_{\text {MARKET }}+\underbrace{\underbrace{\Sigma_{j} S_{i j, t-1}\left(\Delta X_{i j}^{*}-\frac{X_{i j, t-1}^{*}}{X_{i, t-1}^{*}} \Delta X_{i}^{*}-\frac{X_{i j, t-1}^{*}}{X_{j, t-1}^{*}} \Delta X_{j}^{*}\right)}_{\Sigma_{i} \Sigma_{j} X_{i j, t-1}}}_{\text {MIXED STRUCTURE EFFECT }} \\
& \text { EFFECT EFFECT EFFECT }
\end{aligned}
$$

The product and market effects express, respectively, the importance of the product and the geographical structures of a country in the demand side (structure) effect. To complete the structure effect, there is a residual term the mixed structure effect resultant from the solution proposed by Milana (1988), which does not have a straightforward interpretation (ECB 2005).

\section{Decomposing the Relative Growth Rate of Exports}

The second CMSA used in this study is adapted from Nyssens and Poullet (1990) and also adopts Milana's solution. In this case, the total effect is the difference between the exports' growth rate of a country (group of countries) and the exports' growth rate of the rest of the world in the same destination market, weighted by the product and geographical structures of the exporting country(ies). It can be decomposed as follows:

$$
\underbrace{\sum_{i} \Sigma_{j} \theta_{i j} g_{i j}-\Sigma_{i} \Sigma_{j} \theta_{i j}^{*} g_{i j}^{*}}_{\text {TOTAL EFFECT }}=\underbrace{\sum_{i} \Sigma_{j} g_{i j}^{*}\left(\theta_{i j}-\theta_{i j}^{*}\right)}_{\text {STRUCTURE EFFECT }}+\underbrace{\underbrace{}_{i} \Sigma_{j} \theta_{i j}\left(g_{i j}-g_{i j}^{*}\right)}_{\begin{array}{c}
\text { COMPETITIVENESS } \\
\text { EFFECT }
\end{array}}
$$

where $g_{i j}=\frac{X_{i j, t}-X_{i j, t-1}}{X_{i j, t-1}}$ is the export growth rate of a country of product $i$ to the destination market $j$, in period $\mathrm{t} ; \theta_{i j=} \frac{X_{i j, t-1}}{X_{t-1}}$ is the share of product $i$ to destination market $j$ in total exports of the analysed country, in period $t-1$; and $g_{i j}^{*}$ and $\theta_{i j}^{*}$ are the equivalent notions for world exports (excluding the reporting country). A positive (negative) total effect means a total market share gain (loss) of the analysed country in the destination market. The total effect is decomposed into the structure and the competitiveness effects. 
The structure effect captures the difference between the export structure (by product and destination market) of the analysed country and the world weighted by the growth rate of world exports. It will be positive if the country's export structure is more concentrated on high-growth products or markets than the world structure. Note that the term in brackets provides equivalent information to the traditional Balassa's exports performance index of revealed comparative advantage (Amador and Cabral 2008).

The competitiveness effect is a pure market share effect as it measures the aggregated impact of changes in market shares of each product or destination market. It compares the growth rates of the exports of the analysed country and the world that are not due to differences in the export structure.

The structure effect can be decomposed into three effects expressed as follows:

$$
\underbrace{\sum_{i} \Sigma_{j} g_{i j}^{*}\left(\theta_{i j}-\theta_{i j}^{*}\right)}_{\begin{array}{c}
\text { STRUCTURE } \\
\text { EFFECT }
\end{array}}=\underbrace{\Sigma_{i} g_{i}^{*}\left(\theta_{i}-\theta_{i}^{*}\right)}_{\begin{array}{c}
\text { PRODUCT } \\
\text { EFFECT }
\end{array}}+\underbrace{\sum_{j} g_{j}^{*}\left(\theta_{j}-\theta_{j}^{*}\right)}_{\begin{array}{c}
\text { MARKET } \\
\text { EFFECT }
\end{array}}+\underbrace{\sum_{i} \Sigma_{j} g_{i j}^{*}\left[\left(\theta_{i j}-\theta_{i j}^{*}\right)-\frac{\theta_{i j}^{*}}{\theta_{i}^{*}}\left(\theta_{i}-\theta_{i}^{*}\right)-\frac{\theta_{i j}^{*}}{\theta_{j}^{*}}\left(\theta_{j}-\theta_{j}^{*}\right)\right]}_{\text {MIXED STRUCTURE EFFECT }}
$$

The product (market) effect evaluates which part of the structure effect is due to the product (market) specialization of the country analysed. The mixed structure effect is the residual term comprising the interaction between the product and market effects as proposed by Milana (1988).

\section{Main Results}

In what follows, we evaluate the export performance of the ten countries of the 2004 EU enlargement to the EU15, i.e. the total effect of the growth rate and the relative growth rate methodologies above presented (hereinafter referred as export growth rate and relative export growth, respectively). Market share variation is also presented, though not decomposed.

\section{Overall Assessment}

As expected, this new group of EU members had a major improvement in their export performance to the EU15 from 1990 to 2013, as shown in Table 1. In these past 23 years, the exports of manufactured goods to the EU15 increased more than 285 billion USD, corresponding to a growth rate of $1118.3 \%$, and a market share increase in the EU15 of $4.56 \%$, reaching $6.25 \%$ of the EU15's market share in 2013.

The sub-period which registered the highest export performance to the EU15 was the pre-accession one, from 1996 to 2004, with an export growth rate of $186.5 \%$ and a relative export growth of $118.62 \%$, a consequence of country's progresses as preparation for accession. The lowest performance occurred in the aftermath of the economic crisis of 2008, as expected.

With respect to the effects obtained with the decomposition performed in each CMSA, in Table 1 we observe that the competitiveness effect played a dominant and major role in export performance over the whole period. This effect is mainly relevant in the pre- 
Table 1 Decomposition of the export performance with the CMSA (\%)

\begin{tabular}{lllllll}
\hline & & $1990-2013$ & $1990-1996$ & $1996-2004$ & $2004-2008$ & $2008-2013$ \\
\hline \multirow{2}{*}{$\begin{array}{llllll}\text { Market Share Variation* } \\
\text { Export Growth Rate }\end{array}$} & & 4.56 & 0.96 & 1.82 & 0.99 & 0.79 \\
& Total Effect & 1118.30 & 102.18 & 186.65 & 95.04 & 7.78 \\
& Structure Ef. & 241.29 & 22.83 & 58.27 & 56.70 & -9.83 \\
& Product Effect & 222.17 & 23.72 & 62.72 & 52.33 & -12.02 \\
& Market Effect & 228.45 & 28.42 & 64.52 & 63.29 & -4.76 \\
& Mixed Str. Ef. & -209.32 & -29.31 & -68.97 & -58.92 & 6.95 \\
& Comp. Ef. & 877.00 & 79.35 & 128.38 & 38.34 & 17.61 \\
Relative Export Growth & Total Effect & 894.38 & 74.48 & 118.62 & 36.61 & 14.15 \\
& Structure Ef. & 13.32 & -7.79 & -11.59 & -3.22 & -4.88 \\
& Product Effect & -3.35 & -5.72 & -7.13 & -8.46 & -7.19 \\
& Market Effect & -6.47 & -4.68 & -11.67 & 2.95 & -0.55 \\
& Mixed Str. Ef. & 23.14 & 2.60 & 7.21 & 2.29 & 2.86 \\
& Comp. Ef. & 881.06 & 82.27 & 130.22 & 39.83 & 19.03 \\
\hline
\end{tabular}

*Percentage variation in the ten countries' market share $(\Delta S)$ in period $t$

Source: Own calculations from CHELEM database

accession sub-period. In the case of the market and product effects, it is necessary to consider separately the impact on the export growth and the relative export growth.

In the first case, the impact is positive in all sub-periods but the last one, marked by the economic crisis of 2008. It is worth noting that the structure effect surpassed in size the competitiveness effect in the 2004-08 period, showing the importance of full access to the EU15 dynamic market. In the second case, the sign is negative for both the product and market effects in almost all sub-periods (the exception is the market effect in the post-accession sub-period), showing that although the product and market structures of these countries contributed positively to the growth of their exports in the first four sub-periods analysed, the world was relatively more specialized in products and markets with dynamic demand.

\section{Export Performance by Sectors}

Taking into account the ten countries' export performance of manufactured goods to the EU15 by sectors according to their technological level (Table 2), a positive progress in all sectors is acknowledgeable. Considering the overall period, the weakest export performance occurred in the low tech exports, with a growth rate of $527.77 \%$ and a market share increase of $2.03 \%$. The highest export performance took place in high tech exports, with a growth rate of $3172.95 \%$ and a market share increase of $6.67 \%$. Medium tech exports grew at a rate of $1768.12 \%$, registering a market share increase of $6.89 \%$.

Looking closer into the different sub-periods, it is clear that the preparation for the accession to the EU had a positive impact on the technological development of exports from these countries to the EU15. Note, for instance, that the highest market share variation occurs in high tech products in all sub-periods but in the post 2008 crisis. However, this improvement is mainly evident in the pre-accession sub-period, followed by the post-accession one. 
Table 2 CMSA by technological level (\%)

\begin{tabular}{|c|c|c|c|c|c|c|c|c|}
\hline & & \multirow{2}{*}{$\begin{array}{l}\text { Market share } \\
\text { variation* }\end{array}$} & \multicolumn{3}{|c|}{ Export growth rate } & \multicolumn{3}{|c|}{ Relative export growth } \\
\hline & & & Total Ef. & Str. Ef. & Comp. Ef. & Total Ef. & Str. Ef. & Comp. Ef. \\
\hline \multirow[t]{3}{*}{$90-13$} & Low & 2.03 & 527.77 & 242.35 & 285.42 & 222.45 & 47.13 & 175.32 \\
\hline & Medium & 6.89 & 1768.12 & 221.94 & 1546.18 & 360.54 & -7.90 & 368.44 \\
\hline & High & 6.67 & 3172.95 & 244.25 & 2928.71 & 254.97 & -25.57 & 280.54 \\
\hline \multirow[t]{3}{*}{$90-96$} & Low & 1.03 & 72.88 & 18.72 & 54.16 & 37.17 & 0.86 & 36.31 \\
\hline & Medium & 1.05 & 130.68 & 23.78 & 106.89 & 22.18 & -3.27 & 25.45 \\
\hline & High & 1.14 & 249.48 & 43.55 & 205.94 & 15.30 & -4.52 & 19.83 \\
\hline \multirow[t]{3}{*}{$96-04$} & Low & 0.59 & 79.19 & 45.05 & 34.14 & 20.71 & 2.56 & 18.16 \\
\hline & Medium & 2.56 & 250.07 & 65.22 & 184.85 & 47.67 & -3.97 & 51.64 \\
\hline & High & 2.88 & 357.33 & 66.61 & 290.71 & 40.78 & -8.21 & 48.99 \\
\hline \multirow[t]{3}{*}{ 04-08 } & Low & -0.02 & 79.35 & 66.17 & 13.19 & -3.97 & -8.08 & 4.10 \\
\hline & Medium & 1.61 & 101.12 & 54.34 & 46.78 & 18.62 & 2.57 & 16.05 \\
\hline & High & 2.11 & 98.16 & 39.31 & 58.86 & 17.24 & 1.15 & 16.09 \\
\hline \multirow[t]{3}{*}{ 08-13 } & Low & 0.42 & 12.99 & -3.66 & 16.65 & 3.25 & -2.22 & 5.47 \\
\hline & Medium & 1.67 & 15.02 & -7.68 & 22.70 & 7.81 & -0.79 & 8.59 \\
\hline & High & 0.55 & 3.34 & -7.75 & 11.09 & 1.88 & -1.23 & 3.11 \\
\hline
\end{tabular}

* Percentage variation in the ten countries' market share $(\Delta S)$ in period $t$

Source: Own calculations from CHELEM database

Evaluating the different effects in Table 2, it is noteworthy the important positive contribution of the competitiveness effect in both CMSA, mainly in the pre-accession sub-period. This effect is higher for high and medium tech products and particularly in the case of the first. Not surprisingly, considering previous results, the structure effect impacts positively on export growth and negatively on relative export growth of medium and high technology intensity in all sub-periods except the one from 2004 to 2008. The inversion in this last period expresses the increased demand.

Turning now to the analysis by specialization factors shown in Table 3, we observe a positive export performance to the EU15 in all sectors but in those based in natural resources in the immediate post-accession period. Interestingly enough, preparation for accession gave an impetus to the R\&D intensive exports as this sector registered the best export growth in this period, followed by product differentiation and scale economies sectors. In the pre-accession sub-period, export growth and relative export growth of these sectors clearly surpassed the labour cost sector. If we look at the different effects, we conclude that the competitiveness effect has played an important role in the export performance of all sectors and a determinant role in the best performing ones $\mathrm{R} \& \mathrm{D}$, product differentiation and scale economies sectors, namely, once more, in the pre-accession sub-period.

With respect to the structure effect, it is positive for export growth in all sub-periods but in the post-2008 crisis. In this last sub-period, only the natural resources sector resists the demand shrinkage. In line with previous results, the sign of this effect is in general negative in terms of the relative growth rate of exports in all sub-periods, with exception of the labour intensive sectors in the first three sub-periods, product differentiation sectors since the pre- accession period and scale economies sectors in the postaccession period. 
Table 3 CMSA by specialization factors (\%)

\begin{tabular}{|c|c|c|c|c|c|c|c|c|}
\hline & & \multirow{2}{*}{$\begin{array}{l}\text { Market share } \\
\text { variation* }\end{array}$} & \multicolumn{3}{|c|}{ Export growth rate } & \multicolumn{3}{|c|}{ Relative export growth } \\
\hline & & & Total Ef. & Str. Ef. & Comp. Ef. & Total Ef. & Str. Ef. & Comp. Ef. \\
\hline \multirow[t]{5}{*}{$90-13$} & Nat. Res. & 1.08 & 490.97 & 321.49 & 169.48 & 80.90 & 32.85 & 48.05 \\
\hline & L. Costs & 3.91 & 543.66 & 167.74 & 375.92 & 124.81 & 17.35 & 107.47 \\
\hline & Scale Econ. & 7.62 & 1859.67 & 187.36 & 1672.31 & 293.25 & -10.12 & 303.37 \\
\hline & Prod. Dif. & 9.58 & 2308.10 & 230.95 & 2077.15 & 195.59 & -1.72 & 197.31 \\
\hline & $\mathrm{R} \& \mathrm{D}$ & 4.44 & 2402.79 & 252.15 & 2150.64 & 143.41 & -24.69 & 168.10 \\
\hline \multirow[t]{5}{*}{$90-96$} & Nat. Res. & 0.08 & 21.88 & 12.18 & 9.70 & 2.54 & -1.33 & 3.88 \\
\hline & L. Costs & 2.33 & 124.15 & 25.45 & 98.70 & 31.07 & 2.25 & 28.82 \\
\hline & Scale Econ. & 1.12 & 141.25 & 24.91 & 116.33 & 18.45 & -2.74 & 21.19 \\
\hline & Prod. Dif. & 2.26 & 258.82 & 35.99 & 222.84 & 20.84 & -0.39 & 21.23 \\
\hline & $\mathrm{R} \& \mathrm{D}$ & 0.40 & 117.02 & 33.14 & 83.89 & 1.75 & -4.72 & 6.47 \\
\hline \multirow[t]{5}{*}{$96-04$} & Nat. Res. & 0.40 & 82.34 & 59.78 & 22.56 & 3.24 & -0.09 & 3.33 \\
\hline & L. Costs & 0.80 & 68.44 & 33.23 & 35.21 & 14.24 & 2.55 & 11.69 \\
\hline & Scale Econ. & 2.38 & 238.76 & 65.19 & 173.57 & 35.11 & -3.17 & 38.28 \\
\hline & Prod. Dif. & 4.50 & 255.30 & 60.35 & 194.95 & 36.15 & 2.07 & 34.08 \\
\hline & $\mathrm{R} \& \mathrm{D}$ & 2.16 & 448.73 & 78.75 & 369.98 & 20.41 & -10.99 & 31.40 \\
\hline \multirow[t]{5}{*}{ 04-08 } & Nat. Res. & 0.00 & 96.50 & 79.47 & 17.03 & -9.46 & -11.12 & 1.66 \\
\hline & L. Costs & 0.15 & 61.70 & 56.00 & 5.70 & 3.57 & 2.45 & 1.12 \\
\hline & Scale Econ. & 2.00 & 111.59 & 53.86 & 57.73 & 17.29 & 1.88 & 15.41 \\
\hline & Prod. Dif. & 1.47 & 80.92 & 53.26 & 27.66 & 11.04 & 4.98 & 6.06 \\
\hline & $\mathrm{R} \& \mathrm{D}$ & 1.67 & 108.20 & 35.00 & 73.20 & 9.44 & -2.54 & 11.99 \\
\hline \multirow[t]{5}{*}{$08-13$} & Nat. Res. & 0.59 & 35.33 & 4.01 & 31.32 & 1.87 & -2.25 & 4.12 \\
\hline & L. Costs & 0.63 & 5.43 & -3.66 & 9.09 & 1.46 & -0.15 & 1.61 \\
\hline & Scale Econ. & 2.12 & 13.33 & -10.30 & 23.63 & 6.96 & -0.31 & 7.27 \\
\hline & Prod. Dif. & 1.34 & 4.40 & -1.45 & 5.86 & 1.86 & 0.71 & 1.15 \\
\hline & $\mathrm{R} \& \mathrm{D}$ & 0.21 & 0.94 & -15.52 & 16.47 & 0.79 & -2.23 & 3.03 \\
\hline
\end{tabular}

*Percentage variation in the ten countries' market share $(\Delta S)$ in period $t$

Source: Own calculations from CHELEM database

\section{Export Performance by Countries ${ }^{4}$}

Previous results were obtained for the countries analysed as a whole. Yet, analysis by countries shows, according to Table 4, a great amplitude of results in the export performance of these ten economies.

On the one hand, we have the group of the best export performing countries. In the overall period analysed, 1990-2013, they were, by decreasing order, Slovakia, the Czech Republic, Estonia, Poland, Hungary and Lithuania. On the other hand, some countries registered negative relative export growth. This is the case of Latvia, Slovenia, Malta and Cyprus, being these last three the most affected, even showing negative market share growth rates.

In terms of the different effects, analysis of Table 4 puts into evidence the importance of the competitiveness effect for export growth of the best performing countries. An interesting result is this effect being negative in the case of all the worst performing countries above mentioned.

\footnotetext{
${ }^{4}$ For abbreviations of country names used in the Tables, see the two-letter codes supplied by the ISO (International Organization for Standardization). Available at http://data.okfn.org/data/core/country-list.
} 
Table 4 CMSA for each country (1990-2013) (\%)

\begin{tabular}{|c|c|c|c|c|c|c|c|}
\hline & \multirow{2}{*}{$\begin{array}{l}\text { Market share } \\
\text { growth rate }\end{array}$} & \multicolumn{3}{|c|}{ Export growth rate } & \multicolumn{3}{|c|}{ Relative export growth } \\
\hline & & Total Ef. & Str. Ef. & Comp. Ef. & Total Ef. & Str. Ef. & Comp. Ef. \\
\hline $\mathrm{CY}$ & -16.51 & 175.70 & 183.78 & -8.08 & -104.96 & -43.87 & -61.08 \\
\hline $\mathrm{CZ}$ & 658.91 & 2406.12 & 206.94 & 2199.18 & 2126.66 & -23.74 & 2150.40 \\
\hline $\mathrm{EE}$ & 452.22 & 1723.58 & 231.98 & 1491.60 & 783.35 & 2.16 & 781.19 \\
\hline $\mathrm{HU}$ & 224.94 & 973.05 & 237.71 & 735.33 & 736.65 & 13.05 & 723.60 \\
\hline LV & 6.70 & 252.34 & 629.37 & -377.03 & -18.77 & 445.08 & -463.85 \\
\hline $\mathrm{LT}$ & 154.86 & 741.61 & 662.81 & 78.79 & 393.42 & 458.04 & -64.62 \\
\hline MT & -30.34 & 130.02 & 113.65 & 16.38 & -153.71 & -113.07 & -40.63 \\
\hline PL & 344.23 & 1366.96 & 197.77 & 1169.19 & 1106.88 & -24.32 & 1131.19 \\
\hline SK & 1095.05 & 3846.38 & 205.89 & 3640.49 & 3364.54 & -28.67 & 3393.21 \\
\hline SI & -20.06 & 163.98 & 191.09 & -27.12 & -69.11 & -36.91 & -32.20 \\
\hline
\end{tabular}

${ }^{a}$ Due to the different sizes of these ten economies, the market share variation of the previous tables was substituted by the market share growth rate. It is given by $\frac{\Delta S}{S_{t-1}}$

Source: Own calculations from CHELEM database

Regarding the structure effect, it is worth noting the positive influence for the export growth rate of exports in all countries and a negative one for the relative growth of exports in countries with a negative market share growth rate, namely Cyprus, Malta and Slovenia. Such underlines, respectively, the positive importance of the EU15 demand and the negative influence of the specialization pattern initially traced by these three countries, thus reinforcing the negative impact of a poor (negative) competitiveness performance. Other countries were also penalized by the initial specialization pattern but the change in their specialization pattern and increased competitiveness led to notable positive results for exports. It is the case of the Czech Republic, Poland and Slovakia.

Using the two sectoral classifications ${ }^{5}$ enlightens the previous picture. Briefly, we conclude that: (1) all countries but Malta had the highest (lowest) export growth rate and relative export growth in the high (low) technology sectors, considering the overall period analysed (1990-2013); (2) the best performing countries were able to grow from an export profile based on labour costs or natural resources to an export pattern based on other factors more prone to increase value added, as in the case of R\&D, product differentiation, and scale intensive sectors. ${ }^{6}$

The export performance profile of the two best performing countries to the EU15 (the Czech Republic and Slovakia) illustrates previous results. In 1990, the highest exported category of goods of both countries was iron and steel, a scale economies intensive and low tech category of manufactured goods. In 2013, the two highest categories of manufactured goods exported were private automobiles and elements of automobile vehicles, with a medium technology level. In that final year, electrical products, a product differentiation and high tech intensive category of manufactured

\footnotetext{
${ }^{5}$ Given the physical limitation requested for this study, results for the CMSA by technological intensity and specialization factors for each of the ten economies are not presented. They are available upon request.

${ }^{6}$ Since the beginning of the transition process, these countries witnessed a remarkable increase in FDI flows, mainly to Poland, the Czech Republic, Hungary, Slovenia and Slovakia which contributed to the restructuring process and productivity growth in manufacturing (see, for instance, Carstensen and Toubal 2004).
} 
goods, were Czech Republic's third highest export (and Slovakia's fifth) computer hardware and engines were Czech Republic's fourth and fifth highest export, respectively while Slovakia's fourth highest export was consumer electronics, i.e. a high tech and R\&D intensive category of manufactured goods.

\section{Relationship Between the Destination Market and the Competitiveness Effect}

Finally, we have decomposed, in the export growth rate CMSA, the competitiveness effect of the ten states of the 2004 EU enlargement by destination market. The purpose is to evaluate how much of each EU15 destination market absorbs of the variation in the share of the EU enlargement exports over the world exports, i.e. the competitiveness effect. Table 5 presents the results for the ten economies aggregated.

The decomposition procedure was as follows:

$$
\frac{\sum_{i} \Delta S_{i j} X_{i j, t}^{*}}{\sum_{i} \sum_{j} \Delta S_{i j} X_{i j, t}^{*}}
$$

where $X^{*}$ corresponds to the nominal value of world exports $i$ is the category of manufactured goods $j$ corresponds to the EU15 destination market $t$ is the final year and $\Delta S$ is the variation in the share of the analysed country's exports in the world exports in period $t$.

We conclude that Germany was the most relevant destination market in all considered periods. Given its economic weight, such would hardly be a surprise. France, Italy and the United Kingdom have, after Germany, the highest shares, namely in the postaccession period (from 2004 to 2008).

The same analysis was also performed for each country of the 2004 enlargement. Table 6 presents the results in the period from 1990 to 2013. The first line (C.E.) of that

Table 5 Weight of each EU15 market in the ten countries' competitiveness effect* (\%)

\begin{tabular}{llllll}
\hline & $1990-2013$ & $1990-1996$ & $1996-2004$ & $2004-2008$ & $2008-2013$ \\
\hline DE & 45.72 & 55.64 & 48.40 & 20.63 & 40.78 \\
AT & 5.16 & 9.22 & 4.50 & 0.11 & 4.94 \\
DK & 2.35 & 1.83 & 1.71 & 3.88 & 1.82 \\
ES & 4.19 & 1.30 & 5.42 & 6.43 & 6.13 \\
FI & 1.95 & 1.69 & 2.02 & 1.41 & 2.14 \\
FR & 9.51 & 6.73 & 8.83 & 16.32 & 3.81 \\
GR & 0.66 & -0.20 & 0.43 & 2.21 & 1.27 \\
IE & 0.37 & 0.08 & 0.47 & 1.23 & 0.39 \\
IT & 7.65 & 5.53 & 6.80 & 15.73 & 7.86 \\
NL & 3.54 & 4.22 & 3.87 & 8.58 & 9.08 \\
PT & 0.66 & 0.36 & 1.04 & -0.13 & 1.19 \\
GB & 9.34 & 6.26 & 7.34 & 14.49 & 13.17 \\
SE & 4.39 & 3.52 & 4.61 & 4.75 & 2.86 \\
BE & 4.31 & 3.67 & 4.39 & 3.58 & 4.67 \\
LU & 0.21 & 0.14 & 0.17 & 0.78 & -0.11 \\
\hline
\end{tabular}

* Considering the export growth CMSA

Source: Own calculations from CHELEM database 
Table 6 Weight of each EU15 market in each ten countries' competitiveness effect* (\%)

\begin{tabular}{lllllllllll}
\hline & CY & CZ & EE & HU & LV & LT & MT & PL & SK & SI \\
\hline C.E. & - & + & + & + & - & + & + & + & + & - \\
DE & 109.39 & 48.20 & -0.10 & 51.43 & 12.57 & 175.86 & -64.24 & 43.61 & 44.32 & 140.65 \\
AT & -115.56 & 6.78 & 0.54 & 2.74 & -0.49 & 11.24 & 2.65 & 1.69 & 9.36 & -60.06 \\
DK & -37.84 & 1.45 & 4.84 & 1.71 & -7.12 & 47.13 & 30.90 & 2.54 & $1.11 \%$ & -7.91 \\
ES & 56.69 & 3.87 & 0.87 & 5.57 & -0.88 & -85.76 & 144.99 & 4.25 & 4.58 & -0.22 \\
FI & 54.87 & 0.71 & 37.13 & -0.05 & -4.43 & 48.77 & -0.78 & 1.13 & 0.73 & -2.03 \\
FR & 77.03 & 8.33 & 4.30 & 8.43 & 5.41 & 79.00 & 0.51 & 10.05 & 10.62 & 5.29 \\
GR & -839.40 & 0.23 & 0.11 & 0.71 & -0.21 & 3.27 & 79.23 & 0.47 & 0.34 & -3.81 \\
IE & 72.91 & 0.48 & 0.34 & 0.31 & 1.64 & 10.75 & 3.89 & 0.37 & 0.24 & 1.80 \\
IT & 29.03 & 6.29 & 1.32 & $8.30 \%$ & -1.48 & 56.13 & -121.21 & 8.03 & 9.59 & 33.94 \\
NL & -153.21 & 7.43 & 0.56 & 5.60 & 103.45 & -194.45 & 37.94 & 6.24 & 4.25 & -4.52 \\
PT & -5.46 & 0.50 & 0.39 & 0.69 & -0.12 & 8.54 & 12.77 & 0.65 & 0.54 & -2.85 \\
GB & 1041.86 & 8.28 & 3.47 & 9.59 & -6.00 & -120.03 & -54.27 & 11.89 & 8.03 & -5.56 \\
SE & -19.93 & 2.14 & 40.73 & 1.29 & $1.10 \%$ & 110.94 & 33.94 & 4.57 & 2.88 & 3.87 \\
BE & -165.08 & 5.17 & 5.46 & 3.43 & -3.25 & -51.91 & -7.00 & 4.23 & 3.26 & 1.46 \\
LU & -5.28 & 0.14 & 0.05 & 0.25 & -0.18 & 0.53 & 0.68 & 0.26 & 0.15 & -0.04 \\
\hline
\end{tabular}

*Considering the export growth CMSA for the1990 to 2013 period

Source: Own calculations from CHELEM database

table indicates whether the respective 2004 enlargement country registered a positive or a negative competitiveness effect in the overall period.

In Table 6 we detect an interesting pattern: the destination markets which absorbed most of the variation in the market share of the 2004 enlargement countries were those geographically closer. In fact, Germany was the most important destination market for the Czech Republic, Hungary, Poland and Slovakia's competitiveness effect and Austria was the most important for Slovenia's competitiveness effect; considering the Baltic countries, Estonia's most relevant destination markets were Sweden and Finland for Latvia it was Netherland, Denmark, Finland and the United Kingdom while for Lithuania it was Germany and Sweden. Distinctively, for Mediterranean countries were Greece, in the case of Cyprus, and Spain, in the case of Malta.

\section{Conclusions}

This study analyses the evolution of nominal exports of the EU 2004 enlargement countries to the EU15 destination market using two constant market share formulations and a detailed product and geographical breakdown. Those new EU members, when aggregately considered, registered a major improvement in their export performance to the EU15 in all the considered periods from 1990 to 2013. This evolution is most notably in the pre-accession sub-period, as a result of reforms implemented by these countries and EU support preceding full membership.

Based on an identity, one limitation of the study is that the methodology adopted is descriptive rather than explanatory. However, and despite shortcomings in its empirical implementation that have been highlighted in the literature on the topic, some clear-cut inferences on the key factors of export performance of the analyzed countries appear to emerge from the results obtained. Namely, we observe that a decisive contribution to 
their export behavior, measured with the export variation in either absolute terms or relative to the world, was given by increased competitiveness, mainly in the years preparing accession to the EU. The structural effect of this group of economies was also favorable to increased exports but the competitors at the world level in the EU15 market were, in general, more specialized in products and destination markets with dynamic demand. With accession to a larger market in 2004, demand suffered a positive push observable in the reversal of the negative (relative) market effect. However this positive trend would be reversed for most products with the 2008 economic crisis, thus exposing the vulnerability of these countries taken as a group to demand shocks.

We also concluded that the best performing economies of the 2004 EU enlargement counteracted the unfavourable initial specialization pattern with a rapid change in their specialization pattern and increased competitiveness. Interestingly enough, even for the whole set of the 2004 enlargement countries, the highest export performance occurred in high tech exports of manufactured goods followed by medium tech exports while concerning the specialization factors stand out R\&D, followed by product differentiation and scale economies, rather than natural resources or labour costs.

Divergent export performances between the 10 countries were, nevertheless, observed. While Cyprus, Malta and Slovenia registered a negative market share growth rate to the EU15, which this study associates to a negative competitiveness effect and a unfavourable specialization in relation to global competitors, others displayed remarkable positive export performance, supported by increased competitiveness and alteration of the traditional specialization pattern. Such is the case of Slovakia and the Czech Republic, which present the highest values for both growth rates of exports considered in this study in the period 1990 to 2013. Estonia, Poland, Hungary and Lithuania also presented very positive results.

Bearing in mind the ten economies aggregated, the results show that Germany absorbed most of the export growth explained by the competitiveness effect, namely for five of the six best performing economies: the Czech Republic, Hungary, Lithuania, Poland and Slovakia. This is an expected result if we take into account the size of this market. Yet, if the results are evaluated considering each of the ten economies of the 2004 enlargement, a geographical influence is also verifiable, suggesting that those countries tend to drive the most dynamic exports, i.e. those related to competitiveness gains, for countries geographically close.

Acknowledgements Financial support from national funds by FCT (Fundação para a Ciência e a Tecnologia) is acknowledged. This article is part of the Strategic Project: UID/ECO/00436/2013. We are grateful to comments received at the 81st International Atlantic Economic Conference.

\section{Appendix}

Product classification based on CHELEM database and Fernandes (2003)

\begin{tabular}{lll}
\hline Technological level & Specialization factors & \\
\hline Low $\quad$ Cement & Natural Resources & Cement \\
& Ceramics & Manufacture of wood \\
Glass & Paper \\
Iron and Steel & Not elsewhere specified minerals \\
First processing of iron & Coal
\end{tabular}


Technological level Specialization factors

Yarns and Fabrics

Clothing

Garment

Carpet

Leather

Manufacture of wood

Furniture

Paper

Prints

Metal structures

Hardware

Iron ore

Not elsewhere specified minerals

Coal

Crude oil

Natural Gas

Coke

Refined petroleum products

Cereals

Other agricultural products

Inedible agricultural products

Cereal-based products

Fats

Fish and Meat

Animal conserves

Vegetable conserves

Sugar

Animal feed

Beverages

Manufactured tobaccos

Jewellery

Non-monetary gold

Medium Non-ferrous metallurgy

Engines

Farms Equipment

Machine tools

Construction Machines and

Equipment

Watchmaking

Elements of automobile vehicles

Private automobiles

Utility Vehicles

Vessels

Basic mineral chemistry

Fertilizer

Basic organic chemistry

Paintings

Toiletries

Plastics

Plastic articles

Rubber articles

Non-ferrous ores

High Specialised machinery
Crude oil

Natural Gas

Coke

Refined petroleum products

Cereals

Other agricultural products

Inedible agricultural products

Cereal-based products

Fats

Fish and Meat

Animal conserves

Vegetable conserves

Sugar

Animal feed

Beverages

Manufactured tobaccos

Jewellery

Non-monetary gold

Labour Costs Non-ferrous metallurgy

Yarns and Fabrics

Clothing

Garment

Carpet

Leather

Furniture

Metal structures

Hardware

Non-ferrous ores

Scale Economies

Ceramics

Glass

Iron and Steel

First processing of iron

Prints

Elements of automobile vehicles

Private automobiles

Utility Vehicles

Vessels

Fertilizer

Paintings

Toiletries

Plastics

Plastic articles

Rubber articles

Iron ore

Product

Differentiation

Engines

Farms Equipment

Machine tools

Construction Machines and

Equipment

Specialised machinery

Watchmaking

Appliances 


\begin{tabular}{ll} 
Technological level & Specialization factors \\
\hline Weapons & Electric material \\
Measuring instruments & Electrical products \\
Optical instruments & \\
Electronic components & Weapons \\
Consumer electronics & R\&D \\
Telecommunications equipment & Measuring instruments \\
Computer hardware & Optical instruments \\
Appliances & Electronic components \\
Electric material & Consumer electronics \\
Electrical products & Telecommunications equipment \\
Aeronautics and Space & Computer hardware \\
Pharmaceuticals & Aeronautics and Space \\
& Basic mineral chemistry \\
& Basic organic chemistry \\
& Pharmaceuticals \\
\hline
\end{tabular}

Open Access This article is distributed under the terms of the Creative Commons Attribution 4.0 International License (http://creativecommons.org/licenses/by/4.0/), which permits unrestricted use, distribution, and reproduction in any medium, provided you give appropriate credit to the original author(s) and the source, provide a link to the Creative Commons license, and indicate if changes were made.

\section{References}

Ahmadi-Esfahani, F. (2006). Constant market share analysis: uses, limitations and prospects. The Australian Journal of Agricultural and Resource Economics, 50(4), 510-526.

Allard, C. (2009). Central Eastern Europe competitiveness in Central Europe: what has happened since EU accession?, IMF Working Papers, 09/121.

Amador, J., \& Cabral, S. (2008). The Portuguese export performance in perspective: constant market share analysis (pp. 201-221). Banco de Portugal, Autumn: Economic Bulletin.

Carstensen, K., \& Toubal, F. (2004). Foreign direct Investment in Central and Eastern Countries: a dynamic panel analysis. Journal of Comparative Economies, 32(1), 3-22.

Cheptea, A., Gaulier, G., \& Zignago, S. (2005). World trade competitiveness: a disaggregated view by shiftshare analysis. CEPII Working Paper, 23.

ECB. (2005). Competitiveness and the export performance of the euro area. Occasional Paper Series, 30.

EUR-Lex. (2007). The 2004 enlargement: the challenge of a 25-member EU. Available at: http://www.eur-lex. europa.eu/legal-content/EN/TXT/?uri=uriserv:e50017.

Fernandes, C. (2003). The changes in international trade structure and the evolution of Portugal trade specialisation compared to the "triad": The challenges of international competitiveness. Proceedings of the $5^{\text {th }}$ international workshop on European economy. Lisbon: CEDIN/ISEG.

Leamer, E. and Stern, R. (1970). Constant-market-share analysis of export growth. In: E. Leamer, E. and R. Stern (Eds.), Quantitative International Economics (chapter 7, pp. 171-183), $1^{\text {st }}$ ed. Chicago: Aldine Publishing Company.

Milana, C. (1988). Constant-market-shares analysis and index number theory. European Journal of Political Economy, 4(4), 453-478.

Nyssens, A., \& Poullet, G. (1990). Parts de marché des producteurs del'UEBL sur les marches extérieurs et intérieur. In Cahier 7. Banque Nationale de: Belgique.

Pavlíčková, V. (2013). The competitiveness of Slovak foreign trade in the European market. Economic Annals, $\operatorname{LVIII}(196), 7-49$.

Richardson, D. (1971). Some sensitivity tests for a "constant-market-shares" analysis of export growth. The Review of Economics and Statistics, 53(3), 300-304. 